\title{
Pleural Epithelioid Mesothelioma
}

National Cancer Institute

\section{Source}

National Cancer Institute. Pleural Epithelioid Mesothelioma. NCI Thesaurus. Code C45662.

Malignant mesothelioma that arises from the pleura. It is characterized by the presence of cells with epithelioid morphology. The epithelioid cells usually have eosinophilic cytoplasm, bland nuclei, and form tubulopapillary, microglandular, or sheet-like patterns. 